\title{
Activities of the College Overseas
}

\author{
Overseas Desk
}

At its meeting on 8 May 1987 the Executive and Finance Committee received a statement from the then Dean, $\mathrm{Dr}$ Birley, entitled 'The Activities of the College Overseas', and the principle was approved for the establishment of an Overseas Desk within the Dean's Department. It was envisaged that this could be concerned with such matters as education, recognition of experience and training, manpower and professional training; but not with political aspects of psychiatry in other countries. It is planned that one of the Sub-Deans will be particularly associated with the Overseas Desk.

The overseas desk is now to be established within the Dean's Department and we are inviting correspondence on this issue so that the project can be useful in extending the activities of the College overseas. The following are some of the areas in which the Overseas Desk could be involved.

\section{(1) Overseas trainees}

Already fewer people from overseas are having the opportunity to train in psychiatry in the United Kingdom or the Irish republic. Those who do come in future may be wanting some specialist experience to complement the general training in psychiatry that they have received in their home country. In the past the quality of training and its specific usefulness for subsequent practice has often been deficient for trainees from overseas. There has been little attempt to match needs with an appropriate experience of training in this country.

The Overseas Desk will be concerned to investigate ways in which the College might extend its support for nominated overseas trainees. To do this, ways in which other medical Royal Colleges and postgraduate institutions carry out this objective would be looked into. Specific training schemes and consultants, and appropriate training courses in this country would be identified. It would be important to find out what types of training could be provided in which centres. There is a need to establish links with psychiatric organisations in countries from which trainees might come. A very important part of any such scheme is the assessment of the trainee, both in terms of capacity to take advantage of training, and also specific educational needs. Methods of funding should be investigated. This would include both sources of grants or scholarships and also ways in which a trainee could work in suitable established posts in psychiatry (perhaps 'Visitor' posts at the grade of Registrar as envisaged in Hospital Staffing: Achieving a Balance, A Plan for Action, October 1987).
There will be a need for up-to-date information on the General Medical Council and the Irish Medical Council, on the PLAB test, and on Home Office visa requirements. It will thus be necessary to recognise transcultural and other specific needs for different trainees. In this scheme the College may act as agent and arbiter of both the potential trainee and local sponsor and also the potential trainers in the UK and Ireland.

(2) Mutual recognition of psychiatric qualifications Another aspect of the work of the Overseas Desk would be in ways to work out recognition of psychiatric qualifications from other countries. This will involve considering qualifications from:

(i) Europe

(ii) English-speaking countries

(iii) Other countries.

Some preliminary work has already taken place in this area. It will be important for the Overseas Desk to link with organisations in this country dealing with the whole of medicine and its sub-specialties and also with psychiatric bodies in other appropriate countries.

The College has always taken the view that training and examinations must be seen as inseparable. Mutual recognition of examinations can only come about when the training can also be recognised. This, in turn, depends upon the country's developing an efficient, effective and rational system for maintaining good standards of training.

The College does arrange occasional exchanges, as observers, between Examining Boards, whose qualifcations we do recognise (American Boards, Canada, Australia and New Zealand).

\section{(3) Links with, and services for, Members Overseas}

The current Membership list of the College contains about 1,900 Overseas Members and Fellows-a mixture of those who trained for some time in the United Kingdom and have returned to work in their own country and of British doctors who have emigrated. There are also a small and distinguished number of Overseas Honorary Members and Fellows. Some of these people retain a loyalty and affection for the College and continue to receive news of its activities through the Bulletin, and of developments in British psychiatry through the Journal, but their main work is in their local situation and they have no formal link with, or function in, the College's structure. 
The Overseas Desk will be publicised amongst Members of the College who are not resident in Great Britain and Ireland and we hope they will make comments. It would be important to find out what the needs of such Members are, and how they could make use of the Overseas Desk and through it the College, to a greater extent. There may be specific needs for particular countries that the College would be able to meet.

There may well be scope for College meetings to be held overseas. So far there has been a College Regional Meeting held in Pakistan, and a Joint College Meeting held in Bordeaux. There may be scope for the establishment of 'chapters' of the College in other parts of the world.

Should there be a College Overseas Division or Advisers in a formal sense? There is no obvious advantage in such an arrangement, and some disadvantages: there is, for instance, a risk of setting up a parallel group within a country which was seen to be in some respects in competition with the local psychiatric organisation. It would be very difficult to combine the varying needs and interests of different countries. We are, of course, dependent on the recommendation for overseas members for Fellowship upon the existing Fellows in each country.

\section{(4) Psychiatric training overseas}

Especially in those countries with traditional links with the College, there may be scope for the College to be useful in enabling Members of the College resident in this country to teach and take part in other educational activities overseas. This could involve examining and approving training, and, of course, these three aspects of teaching, examining and approving psychiatric educational facilities already takes place to some extent.

For instance, the College has recommended external examiners to take part in local postgraduate psychiatric examinations, in Singapore and Sri Lanka. Also, examiners from abroad involved in setting up or improving local examinations have, on occasions, observed the examination procedures and standards of the College.

Many overseas countries are hard pressed to pay for a teacher or a trainee to come to the UK for a period of academic refreshment or training in research. The College and the overseas country might try to raise money, from an external source, to support such schemes. We hope to initiate such a scheme with our colleagues in Pakistan with the help of a pharmaceutical company.

\section{(5) Matters of psychiatric concern in other countries}

There are a number of other areas in which the College would have an interest and involvement in psychiatric practice in other countries. Some of these matters will be dealt with already in other Committees, Working Parties and Groups within the College, and are not the concern of the Overseas Desk.

These are at the moment only ideas and suggestions. To convert them into reality, Members and Fellows of the College, and especially those overseas, should let us know which of these options they regard as important and what other aspects of the functions of the College could be used more effectively if their individual needs and local situations were taken into account.

Professor ANDREW Sims

Dean

\section{Overseas Page}

At any one time about $25 \%$ of our members are resident overseas, many returning to their home centres after training in the United Kingdom.

Some of them have suggested that it would help them to keep in touch with the remaining members of the College if there were a page of the Bulletin devoted to contributions from overseas colleagues. This suggestion was welcomed and agreed by the Executive and Finance Committee. Members residing abroad are now invited to send letters, articles or other material for this purpose, addressed to the Editors of the Bulletin.
Professor R. G. Priest Registrar 